\title{
Assessment of Aesthetic Valeus of Old Oyo National Park
}

\author{
Oladeji S. O ${ }^{1, *}$, Agbelusi E. A ${ }^{1}$, Ajiboye A. S. ${ }^{2}$ \\ ${ }^{1}$ Department of Ecotourism and Wildlife Management, Federal University of Technology, Akure, P.M.B. 704, Akure \\ ${ }^{2}$ Department of Statistical Science, Federal University of Technology, Akure. P.M.B 704, Akure
}

\begin{abstract}
The assessment of aesthetic values and a wide range of cultural and natural heritage resources in the Old Oyo National Park were investigated. These resources were classified into four ecotourism features. The ir aesthetic values were carried out through objective (Expert 's judgement) and subjective (public preference) methods of landscape assessment. Descriptive inventory was carried out through transects walk while public preference involves administration of questionnaires to the tourists. On the basis of objective method, the four classified features were subdivided into four characters and tabulated against tourist elements. The ecotourism features scored on the tourist elements were analyzed using chi-square test of homogeneity; it was concluded that the ecotourism features do not score equally on the various tourist elements. The result of subjective method revealed that the fauna resources have the highest scenic attractions supporting diverse ecotourism activities. However, the result of the descriptive inventory revealed that the hydrological features consisting of Dam Lake, Rivers and their tributaries and hand dug well scored highest on the seven categories of tourism elements compared with other ecotourism features. This research output will assist the management of Old Oyo National Park in integrating aesthetic value assessments and implementation as part of the planning process.
\end{abstract}

Keywo rds Aesthetic values, Cultural heritage tourists, Natural resources, Old Oyo Nat ional Park, Objective, Subjective method, Ecotourism, Scenic attractions

\section{Introduction}

Assessment is a tool which can make a significant contribution to the objectives that relate to 'environmental protection' and 'prudent resource use' as corner-stones of sustainable development[1]. The assessment of the values attributed to heritage is an important activity in any conservation effort, since values strongly shape the decisions that are made[2]. Aesthetic values are considered as the most comprehensive and balanced typology[3]. Value has always been the reason underlying heritage conservation because it is self-evident that no society makes an effort to conserve what it does not value[4]. Heritage has been defined as our legacy from the past, what we live with today, and what we pass on to the future generation[5]. Our culture and natural heritage are both irreplaceable sources of life and inspiration. They are our touchstones, our points of reference, our identity. Therefore, we hold it a duty to protect and preserve these resources for the future generation. The United Nations Educational, Scientific and Cultural Organizations (UNESCO) seek to encourage the identification, protection and preservation of cultural and natural heritage around the world that are considered to be outstanding value to humanity.

* Corresponding author:

oladejisunny@yahoo.com (Oladeji S. O)

Published online at http://journal.sapub.org/tourism

Copyright (C) 2012 Scientific \& Academic Publishing. All Rights Reserved
Old Oyo National Park (OONP) is considered as a mixed heritage site with outstanding natural and cultural values that if explored could serve as basis for its enlistment on the UNESCO world heritage list as the first mixed heritage site in Nigeria[6].OONP is a landscape that serves various purposes which include recreational site, gene pool of immensurable biodiversity and research laboratory for students and researchers in the field of archeology, anthropology, ecotourism, wildlife, botany, zoology, ethnobotany and wild life. National parks and other protected areas have become popular destinations for nature tourism and ecotourism, both of which are rapidly becoming important components of the international tourism industry [7]. According to the World Touris m Organisation (WTO) ecotourism generated revenue of about US $\$ 20$ billion a year and, in comb ination with nature tourism, contributed to $20 \%$ of global international travel[7].

Landscape is about the relationship between people and place. It provides the setting for our day-to-day lives. It results from the way that different components of our environment - both natural (the influences of geology, soils, climate, flora and fauna) and cultural (the historical and current impact of land use, settlement, enclosure and other human interventions) - interact together and are perceived by human being. Subjective and objective methods of landscape assessment are good tools to be adopted in aesthetic values assessment. These methods referred to as public preference and expert judgment, respectively[8],[9],[10]. 
Unfortunately, the management plan prepared for the OONP about twenty years ago did not incorporate values assessment in its planning and recommendations[11]. It is against this back drop that Nigeria National Park Service as a government body saddle with responsibility to oversee management of the seven National Parks in Nigeria is charge to emu late countries such as Australia ICOMOS, the United States National Park Service, Parks Canada and English Heritage who have developed integrated planning methodologies that incorporate values in conservation decision making. Planning approaches should integrate issues of values with other contextual considerations like available resources, legislative environment, as well as the more technical issues of physical condition. The underlying tenet is that a thorough, holistic and integrated analys is of all these considerations paves way for clear conservation policy that is sustainable in the long term[2]. Nigeria government should take a giant step to follow suit with the mentioned countries. Aesthetic value ass essment can also serve as bas is for carrying out Visual Impact Assessment since the management are predetermined the impact any of their proposed development will have on the ecotourism resources in the Park based on how these resources attracts the tourists and the expert judgment. Four steps are suggested for integrating value assessments and implementation as part of the planning process. The steps are creating statements of significance, matching values to physical resources and site characteristics, analyzing threats and opportunities, and making policies and taking actions[2]. Old Oyo National Park is being threatened by anthropogenic activities of the host communities[12]. Decision making and policy formulation for comprehensive resource planning and management of OONP would be enhanced with the availability of the assessment of aesthetic values of its natural and cultural landscape.

This study is therefore is considered as part of the step towards policies and decisions making gears towards ecotourism planning and formulating sustainable conservation policy.

\section{Methodology}

\subsection{Study Area}

\subsubsection{Location, Size and Boundary}

Old Oyo National Park is geographically located between North latitudes $8^{\circ} 10^{\prime}$ and $9^{\circ} 05^{\prime}$, and East longitudes $3^{\circ} 35^{\prime}$ and $4^{\circ} 21^{\prime}$, and centered on North latitude $8^{\circ} 36^{\prime} 00^{\prime \prime}$ and East longitude $3^{\circ} 57^{\prime} 05^{\prime \prime}$. The Park covers a land area of approximately $2,512 \mathrm{~km}^{2}$ making it the fourth largest national park in Nigeria. Po litically, it lies in Oyo State in the Southwest of Nigeria and borders Kwara State in the Northeast. It is surrounded by ten (10) Local Government Areas in Oyo State namely: Atisbo ( Tede/Ago-Are)
3.4220E, 8.5420N), Atiba (Oyo) (3.9260E, 7.8400N), Irepo (Kisi) (3.8510E, 9.079N), Oore lope (Igboho) (3.7550 E, 8.8340N), Saki East (Ago-Amodu) (3.6100E, 8.6090N), Is eyin (Is eyin) $(3.5760 \mathrm{E}, 7.9590 \mathrm{~N})$, Orire (Ikoyi) $(4.1690 \mathrm{E}$, $8.2700 \mathrm{~N})$, Itesiwaju (Otu) (3.3970E, 8.2110N), Olorunsogo (Igbeti (4.1350E, 8.7450N), Saki West (Saki) (3.3860E, $8.6620 \mathrm{~N})$ and Kaima Local Government Area in Kwara State. Figure 1 shows the location of Old Oyo National Park and the adjourning communities.

\subsubsection{Flora}

Vegetation of the OONP has been classified as Southern Gu inea Savanna[13]. However more intense studies by[14] classifies the Southern portion of the vegetation as Forest savanna Mosaic with wooded savanna containing relic of Moist Semi decidious forest, grading northwards into drier Mixed Leguminous Wooded Savanna with a continuous lower stratum of perennial grasses. The vegetation was further analyzed and classified into four broad groups including Dense woodland and Forest outlier in the Southern portion and the North West corner, Mixed open savanna in the middle and North east portions, Outcrop vegetation in the hilly and rocky areas and Riparian grassland and fringing woodland and forest vary along major rivers and streams dominated[15]. The team of experts working on the management plan of the park described and recognizes four broad ecozones to include forest and dense savanna mosaic woodland of the park around Sepeteri axis designated as site A, dense and open savanna woodland mosaic in the central portion of the park, Dense savanna woodland, north of Igbeti-Kishi axis zone $\mathrm{C}$ and Open savanna woodland, North-east of the park (Oyo-Ile sector)[11].

\subsubsection{Fauna}

Animals like Lion, Leopard, Greater bustard, Spotted hyeana, Serval cat, Aadvark, Elephant, Buffalo, Kob, Waterbuck, Reed buck, Oribi, Roan antelope, Hartebeest Bush buck, Spotted hyena, Common warthog, Red river hog, Red flanked duiker, Bush buck, Mongoose, Maxwell's duiker, Patas monkey, Tantallus monkey, Olive baboon, Hunting dog and Mangabey were sighted in the OONP[16], [17],[11],[18].

\subsubsection{Watersheds and Drainage Patterns}

There are three watersheds in Old Oyo National Park: River Ogun and its numerous tributaries, River Tessi and its tributaries and River Iwa and its tributaries. Ogun River flows southwards to the Atlantic Ocean. Several tributaries notably Oopo, Iwawa, Oowe and Owu flow southwestwards and southeastwards join it before its exit from the park. The Tessi River flows northwards to the River Niger. Three ma in tributaries including River Soro join it before its exist from the park. The Iwa River flows northeastwards to the River Niger. 


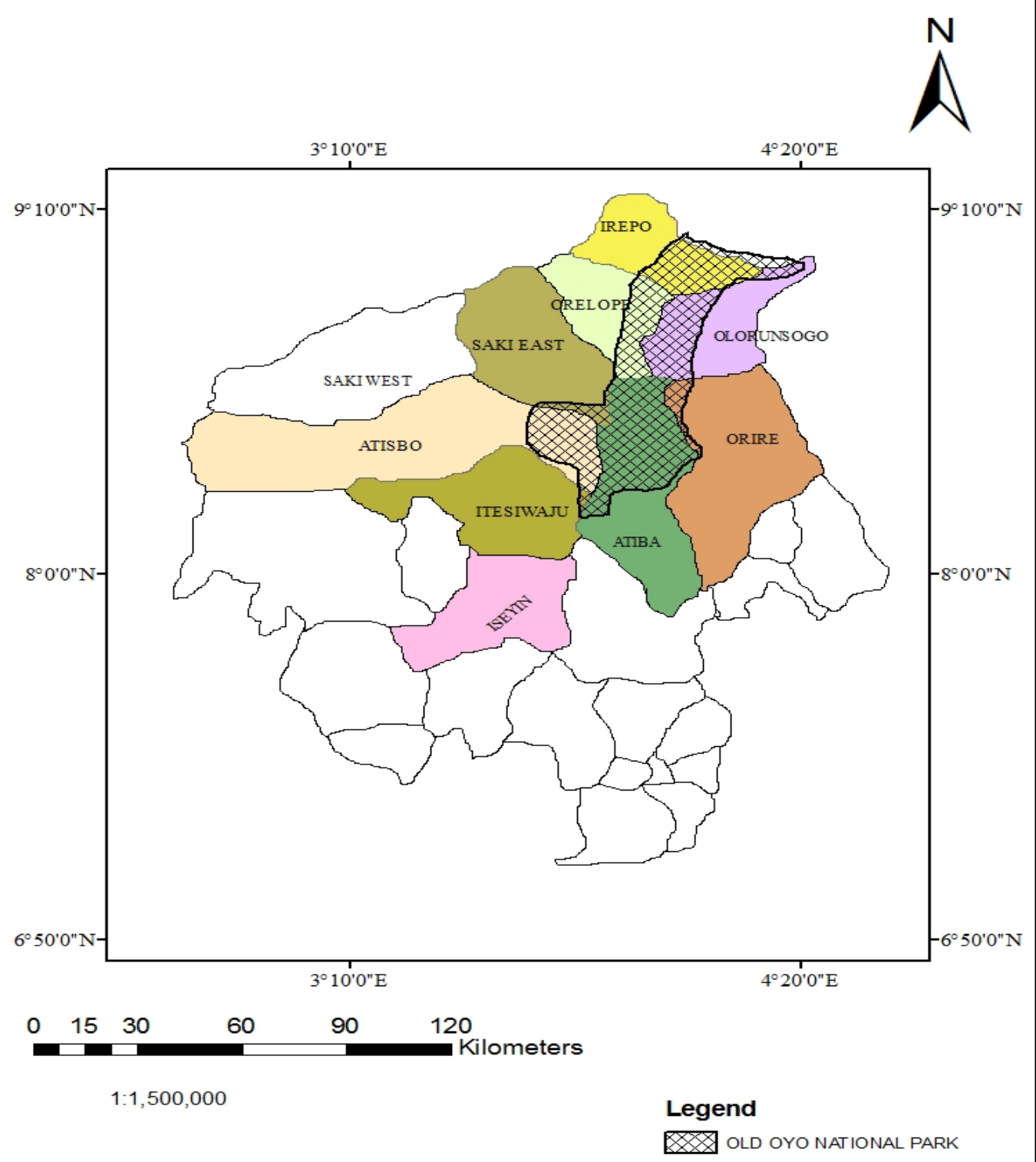

Figure 1. Map of Oyo State showing location of Old Oyo National Park and adjourning communities (Source: Computed From 2009 Field Survey)

\subsubsection{Surface Water}

The construction of a dam at Ikere Gorge on the Ogun River about $4 \mathrm{~km}$ south of the park holds a very large body of water reaching up to $10 \mathrm{~km}$ or more upstream of Rivers Owu, Ogun and Oowe. Otherwise, all the rivers and streams in the park are seasonal and cease to flow during the dry season. However, the major rivers break into pools some quite large, but the Ogun River maintains a very low discharge rate during this period.

\subsection{Method of Data Collection}

Assessment of the aesthetic values of the ecotourism resources in Old Oyo National Park Natural and Cultural Landscape was carried out using research methodologies as emphasised by[19],[20]. The first one was subjective method typically categorized as public preference methodology and the second one was objective method that fall under the category of expert's judgement [21].

\section{Reconnaiss ance Survey}

Prior to the commencement of this research work repeated visits were made to the Head office of the Park in Oyo and subsequently to all the five administrative ranges with their headquarters in Tede, Igboho, Igbeti, Ikoyi and Sepeteri for a period of two months with a view to identify the suitable methods to adopt for this study. Secondary data was collected in form of record of the tourist's influx to the Park from inception

\section{Objective method}

Objective method was carried out through field observation using existing trails as transects except in some 
places where accessibilities was impaired. Three out of the five administrative ranges the Park was cartegorised were selected purposively for this study as identified during the reconnaissance survey. The selected ranges and their headquarters are Tede range with the headquarter in Tede, Sepeteri range with headquarter in Igboho and Oyo-Ile range with headquarter in Igbeti. The field observation involves traversing two of the existing observation trails as transects in each range making a total of six transects in the morning immed iately after the sun rise and in the evening before the sun set for three consecutive days per month over a period of four months in each of the study year of 2008 and 2009. The researchers were accompanied by research officers of the Park and the Park rangers assigned for this research work.

\section{Subjective method}

A total of five hundred respondents representing about $10 \%$ of the tourist influx between the study period of 2008 and 2009 were surveyed for the public preference methodology. The questionnaire sought information basically on the socio-economic characteristics of the respondents

\section{Hypothesis}

Ho: The four ecotourism features score equally on the 7 categories of Tourist elements (i.e. there is homogeneity of the ecotourism features in their scores on the list of tourist elements.

H1 : No homogeneity among the four Ecotourism features
Decision rule: When range of $\mathrm{P}$-value $<\alpha=0.05$ level, Ho is rejected, if otherwise accept Ho

\section{Results}

\section{Analysis of the secondary data}

Tourist record to the Park was plotted to show the trend of the influx (Figure 2). Do mestic tourists represent $97 \%$ of the total tourist influx to the Park since its inception to 2009 while international tourist represents 3\%.

\section{Subjective Method Categorized as Public Preference Methodol ogy}

Quantitative assessment is regarded as subjective based on individual preference (tourist preference). The adoption of this method was based on the notion that public preference evaluation method is the best source of data for assessing landscape quality in that general public and the visual attractiveness of the landscape is ultimately a product of the aggregated opinion of all the individual concerned with that landscape[19].The need to provide demographic information on the socio-economic activities of the respondents have necessitated the administration of questionnaires. A total of five hundred questionnaires were administered to the touris ts who visited the park during the study period. The results obtained are presented in Tables $1 \& 2$.

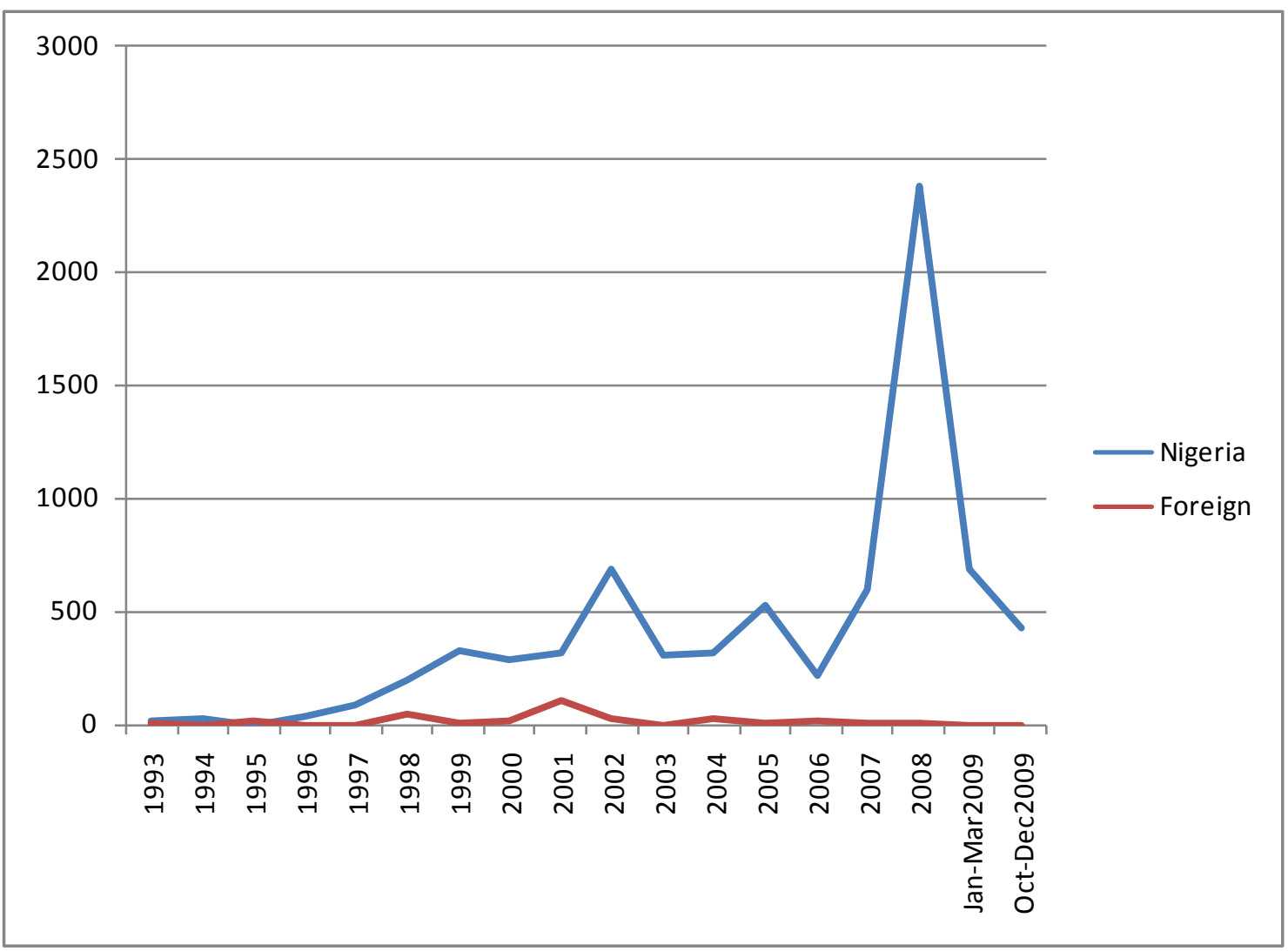

Source: OONP

Figure 2. Trend analysis of domestic and International tourists' influx to the Park from 1993-2009 
Table 1. Summary of socio-economic characteristics of the tourists

\begin{tabular}{|c|c|c|}
\hline Respondents & $\begin{array}{l}\text { Number of } \\
\text { respondent/ } \\
\text { frequency }\end{array}$ & Percentage \\
\hline \multicolumn{3}{|l|}{ Age } \\
\hline$>20$ & 72 & 143 \\
\hline $21-40$ & 204 & 40.8 \\
\hline $41-60$ & 194 & $\begin{array}{l}40.0 \\
38.8\end{array}$ \\
\hline $61-80$ & 30 & $\begin{array}{c}50.0 \\
6.1\end{array}$ \\
\hline Total & $\begin{array}{c}30 \\
500\end{array}$ & $\begin{array}{c}0.1 \\
100\end{array}$ \\
\hline Sex & & \\
\hline $\begin{array}{l}\text { Male } \\
\text { Female }\end{array}$ & 306 & 61.2 \\
\hline Female & 194 & 38.8 \\
\hline Total & \multirow{2}{*}{\multicolumn{2}{|c|}{ Marital status }} \\
\hline $\begin{array}{l}\text { Marital status } \\
\text { Single }\end{array}$ & & \\
\hline Married & 266 & 53.1 \\
\hline Total & 234 & 46.9 \\
\hline \multicolumn{3}{|l|}{ Religion } \\
\hline Christian & 258 & 51.7 \\
\hline Muslim & 220 & 43.9 \\
\hline Traditionalist & 22 & 4.4 \\
\hline Total & 500 & 100 \\
\hline \multicolumn{3}{|l|}{ Non-civil servant } \\
\hline student/researcher & 75 & 15.0 \\
\hline Business & 204 & 40.8 \\
\hline Civil-servant & 134 & 26.9 \\
\hline No response & 75 & 15.0 \\
\hline Total & 12 & 2.4 \\
\hline & 500 & 100 \\
\hline \multicolumn{3}{|l|}{ Level of income/per } \\
\hline $\begin{array}{l}\text { annum } \\
>100000\end{array}$ & 29 & 5.8 \\
\hline $101,000-200,000$ & 27 & 5.4 \\
\hline $201,000-300,000$ & 21 & 4.1 \\
\hline $301,000-400,000$ & 24 & 4.8 \\
\hline $401,000-500,000$ & 44 & 8.8 \\
\hline $501,000-600,000$ & 20 & 4.1 \\
\hline $601,000-700,000$ & 30 & 6.1 \\
\hline $701,000-800,000$ & 220 & 44 \\
\hline $801,000-900,000$ & 26 & 5.1 \\
\hline $901,000-1,000,000$ & 25 & 5.1 \\
\hline$>1,000,000$ & 33 & 6.5 \\
\hline Total & 500 & 100 \\
\hline \multicolumn{3}{|l|}{ Town/State tourists } \\
\hline were from & 102 & 20.4 \\
\hline Oyo & 84 & 16.8 \\
\hline Ogun & 68 & 13.5 \\
\hline Lagos & 56 & 11.2 \\
\hline Ondo & 33 & 6.6 \\
\hline Ekiti & 30 & 6.1 \\
\hline Osun & 21 & 4.1 \\
\hline Kwara & 75 & 15.0 \\
\hline Kogi & 31 & 6.2 \\
\hline Abuja & 500 & 100 \\
\hline
\end{tabular}

Source: Computed from 2008/2009 Field survey

Tourists between the age of 21-40 years recorded the highest percentage (41\%) (Table 1). Male constituted $61 \%$ while the female represented $38.8 \%$ of the tourists. The data also indicated that unmarried were $53 \%$ while married were $47 \%$ of people who visited the Park. Also, Christians constituted the highest percentage (52\%). OONP witnessed the visits of students and researchers $(40.8 \%)$ in the field of tourism, botany, zoology, wildlife, forestry, anthropology, archeology during the study period. Touris ts from Oyo State constituted the highest percentage of $20 \%$, followed by those from Ogun State with 17\%, Kogi State 15\%, Lagos State $13 \%$ while tourists from Kwara State constituted the least (4\%). Income earners of between $\$ 601,000$ - $\$ 700,000$ recorded the highest percentage of $44 \%$ and there were close variations in the income level as obtained for other respondents.

Fauna resources took the lead of attractions as indicated by $40 \%$ of the respondents, this include those who prefer to engage in activities such as game viewing, bird watching e.t.c. Th is was followed by those visiting for cultural heritage tourism $(22 \%)$. Next to these were the tourists attracted by geological formations (18\%)

Table 2. Tourist's preference to the Park

\begin{tabular}{ccc}
\hline Attractions & Frequency & Percentage \\
\hline $\begin{array}{c}\text { Flora resources } \\
\text { /vegetation variations } \\
\text { Hydrological } \\
\text { formations e.g. }\end{array}$ & 62 & 11 \\
lakes, rivers, streams & 58 & 9.9 \\
\hline $\begin{array}{c}\text { Fauna resources e.g. } \\
\text { wild animals, birds , } \\
\text { fishes }\end{array}$ & 234 & \\
$\begin{array}{c}\text { Geological formations } \\
\text { e.g. hills, mountains , } \\
\text { caves }\end{array}$ & & 40 \\
$\begin{array}{c}\text { Cultural heritage } \\
\text { resources } \\
* * \text { Total }\end{array}$ & 105 & 17.8 \\
\hline$*$ Multiple response & 129 & 21.9 \\
& 588 & 100 \\
\hline
\end{tabular}

\section{Objective method: Expert's judg ment}

Qualitative approaches was described as those which focus upon the evaluation of the complexity of landscape using the judgment of panels of human subjects, and quantitative approaches as those with measure physical characteristics of the visual field[22].

Objective method includes ecological and formalaesthetic models methods which are mostly applied by experts in an objective manner. It has been used in assessment of the visual quality of a landscape - a phrase synonymous with beauty or aesthetic but intended to convey an impression of objectivity [23]. The result obtained is as shown in Table 2.

Pleasant weather was omitted as part of the tourism elements because OONP is in the Northern Guinea savanna of Nigeria where temperature range is between $27-30{ }^{\circ} \mathrm{C}$ unlike places like Obudu in Cross river State in Nigeria with temperature range of between $7-15^{\circ} \mathrm{C}$. This temperature range $\left(7-15^{\circ} \mathrm{C}\right)$ has been considered a major attractions drawing international tourists to Obudu cattle ranch over the years [24]. Thus the temperature range in OONP has not been recorded as attraction to the site. 
Table 3. Expert's judgement of Ecotourism features of Old Oyo National Park

\begin{tabular}{|c|c|c|c|c|c|}
\hline & \multicolumn{4}{|c|}{ Ecotourism Features } & Total \\
\hline Tourist elements & $\begin{array}{c}\text { Hydrological } \\
\text { Features }\end{array}$ & $\begin{array}{c}\text { Geological } \\
\text { Features }\end{array}$ & $\begin{array}{c}\text { Historical } \\
\text { Features }\end{array}$ & $\begin{array}{c}\text { Wildlife } \\
\text { Features }\end{array}$ & \\
\hline Historical/ cultural factors & 7 & 5 & 10 & 0 & 22 \\
Scenic Attraction & 14 & 12 & 10 & 16 & 52 \\
Accessibility & 5 & 5 & 5 & 2 & 17 \\
Amenities & 17 & 15 & 15 & 2 & 49 \\
Accomodation & 8 & 8 & 8 & 2 & 26 \\
Safety and Security & 5 & 5 & 5 & 2 & 17 \\
Others & 20 & 22 & 22 & 2 & 66 \\
Total & 76 & 72 & 75 & 26 & 249 \\
\hline
\end{tabular}

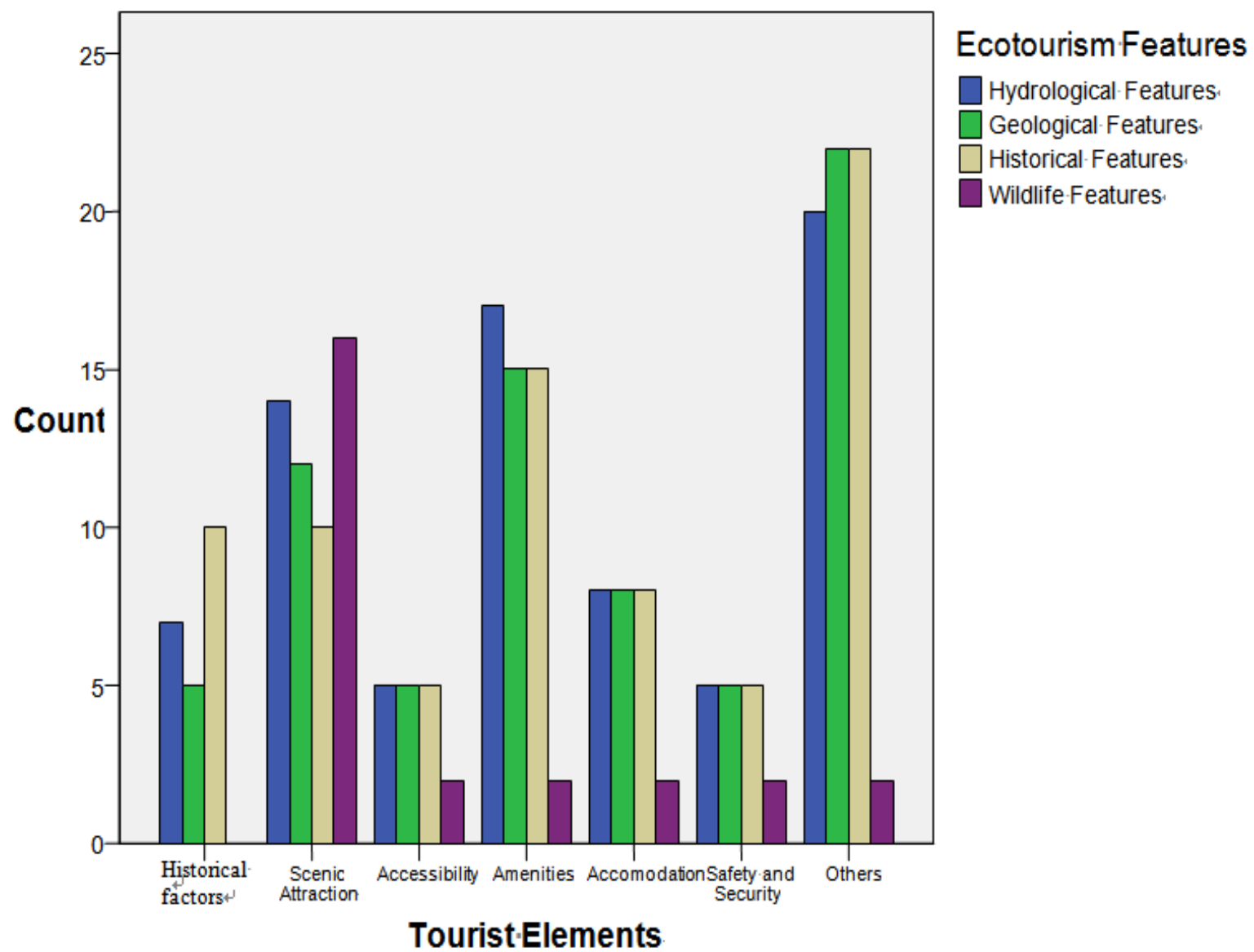

Figure 3. Bar chart showing relationship between Tourist elements and ecotourism features

The ecotourism features were tabulated against tourist elements. How the ecotourism features scored on the tourist elements were then analyzed using statistical method. The hypothes is that the four categories of ecotourism features i.e. hydrological, Geological, Historical and wild life score equally on the various tourist elements is tested against the alternative hypothesis that at least one ecotourism feature scores differently from the others. The test statistic was the chi-square test of homogeneity and the level of significance was 0.05 . The analys is showed a significance probability of 0.011 which is less than 0.05 (Table 4). The null hypothes is is therefore rejected and we conclude that the ecotourism features do not score equally on the various tourist elements.
The result shows that wildlife resources are significantly lower from the other features (Table 3 ).

Table 4. SPSS Result of the analysis of the data in Table 13

\begin{tabular}{|c|c|c|c|}
\hline & Value & Df & $\begin{array}{c}\text { Asymp. Sig. } \\
(2 \text {-sided })\end{array}$ \\
\hline Pearson Chi-Square & $34.454(\mathrm{a})$ & 18 & .011 \\
\hline Likelihood Ratio & 31.679 & 18 & .024 \\
\hline $\begin{array}{c}\text { Linear-by-Linear } \\
\text { Association }\end{array}$ & 2.665 & 1 & .103 \\
\hline N of Valid Cases & 249 & & \\
\hline
\end{tabular}

At a significance probability of 0.05 , we reject $\mathrm{H} 0$ since 
the significance probability is $0.011<0.05$ which is the level of significance for the test. In conclusion, the four ecotourism features do not score equally on the 7 categories of tourist elements.

This shows that wildlife features scored less than the other features on the various tourist elements. This is clearly demonstrated in the bar chart of Figure 3

\section{Discussion}

Aesthetic value is a strong contributor to a sense of well being and is perhaps the most personal and individualistic of the socio-cultural value types[25].The primary and secondary data collected on the tourists visit to the park revealed that over $90 \%$ of the tourist patronage to the Park before and during the study period were domestic tourists. This is not peculiar to Old Oyo National park a lone. Study on the number of domestic and international patronage to Obudu cattle ranch in Cross River state revealed that the total number of Nigerian tourists that visited the ranch supersedes that of foreign visitors in the recent years [24]. Domestic tourist patronages to the park during the study period were drawn from neighboring states. It has been internationally acknowledged that tourist currently accounts for approximately $80 \%$ of all tourists' activity[26]. The Australian National and International Visitor Surveys profiles on the Ecotourists to Australia revealed that majority of the nature tourism market for New South Wales (84\%) comes from within Australia (domestic market). The tourists seeking interactions with wildlife in their natural environments is also increasing across the World[27],[28]. This general interest in nature and nature-based experiences is reflected in an increasing demand and value being placed on animals in the wild, as opposed to those in captive or semi-captive situations [29]. The same could be deduced fro $m$ this study as reflected from the result obtained from the administered questionnaires through quantitative assessment method based on individual preference (tourist preference).. Greater percentage of the tourist representing $36 \%$ of the respondents prefer visiting the Park to observe fauna resources that are providing amenities for bird watching, game viewing, wilderness experience etc. Others include cultural heritage tourists (22\%), those attracted by the geological formations (18\%). Age between 21-40 (41\%) was recorded to have highest tourists followed by those in the age range of 41-60 (39\%). This supports the research findings[30] on the profile of ecotourists in Europe that their age is between middle-age to elderly. Based on data collected through a survey completed by HLA and ARA, it was also observed that the age range of the tourists (nature based and wildlife tourists) were in the age range of 35-54 years old ( male to female ratio was found to be equal although clear differences by activities were found[31]. The fact that male constituted the highest percentage $(61 \%)$ of the tourists than female which represents $39 \%$ and that the unmarried (53\%) visited the Park than married (47\%). This is in agreement with the findings of[32]. It was also reported that definite nature tourist come from Northern European countries are more likely to be male, more likely to be single, highly likely to be aged between 20-34 years and either earn under $\$ 30,000$ or over $\$ 100,000$ [33].

Old Oyo National Park witnessed the visits of students and researchers during the study period representing $(41 \%)$ of the total number of tourists. It has been reported that visits by ecotourists from higher education was reported in Europe[30]. This shows a clear difference based on the observation of HLA and ARA consulting firms of North America that there had been a shift in interest in ecotourism from those who have high levels of education to those with less education indicating an expansion into mainstream markets. Higher income bracket was recorded across Europe for the ecotourists, the same could be deduced fro $m$ this study. Income earners of between $\$ 601,000$ - $\$ 700,000$ shows the highest percentage of $44 \%$ ( there were close variations in the income level as obtained for other respondents). With low growth in the economy, the rise in discretionary spending levels (those not required for basic living) will remain miniscule (NTDMP, 2006). When there are increase in wages, salaries and imp rove standard of living of the people in the country there will be increase in discretional income. Plans to budget part of discretionary time and money for tourism and recreational activities in the future was greater among Nigerians males with $62 \%$ than the female (38\%)[32]. According to HLA and ARA[31] experienced ecotourists were willing to spend more than general tourists, the largest group (26\%) stating they were prepared to spend $\$ 1,001-\$ 1,500$ per trip.

Apart from quantitative assessment method, descriptive inventory described as qualitative approach[22] was equally adopted for the aesthetic value assessment. Hence, the assessment of aesthetic values of OONP was carried out through subjective and objective methods[23]. Three types of landscape evaluation models have been described encompassing a diverse range of techniques[33]. One of it is descriptive inventory model which defined values by formal aesthetic models or ecolog ical classification which is mostly applied by experts in an objective manner. It has been used in assessment of the visual quality of a landscape - a phrase synonymous with beauty or aesthetic but intended to convey an impression of objectivity[23]. Expert's judgement was carried out in this research work through field observation and Interviewed of some of the Park staff especially those in Park Protection and Conservation Unit that were assigned and accompanied the researchers in the course of carrying out this study [34],[35],[18]. These are some of the methods introduced relatively recently to assess socialvalues, and they are already being used to bring new groups of stakeholders into the values identification process [25]. The research findings revealed that through public prefrence method adopted, the fauna resources are the major attractions to the Park. However the result of the descriptive inventory revealed that the hydrological features consisting 
of Ikerre Gorge Dam Lake, Ibuya pool, Rivers and their tributaries, water reservoirs and hand dug well scored highest on the seven categories of tourism elements compared with other ecotourism features like wildlife resources, historical/cultural formations and geological formations. The ecotourism potentials of Ikerre Gorge Dam Lake, Ibuya pool, rivers and tributaries have been emphasized[17],[18],[36],[37]. A clean smelling lake is a source of pure pleasure, and provides a sustainable living to countless species of the aquatic ecosystem like fish, birds, insects, microorganism and aquatic vegetation[38]. The result of the Duncan multiple test revealed that the wildlife features recorded the least, they however have the highest scenic attractions. Unlike other ecotourism features the wildlife resources lack associated historical/cultural factors, this may not be of interest to the tourist except the cultural heritage tourists.

\section{Conclusions}

This study aimed at providing information that will be of assistance in integrating value assessment into the ecotourism management plan of Old Oyo National Park. It also serves as a basis for carrying out visual impact assessment of the Park. The fauna resources were revealed to attract greater percentage of the tourists based on the subjective method of public preference method conducted. However hydrological formations provided the highest aesthetic values having scored highest on tourist elements / features scale according to the result obtained through objective - descriptive inventory. The Park Conservation Authority will benefit tremendously if efforts could be put in place to maximize the aesthetic values of these features. Roads should be constructed and should be readily accessible all the year round for the tourist especially to places where these hydrological formations were sighted. Another impediment to full exploitation of the aesthetic values of the hydrological formations and some other features is the poor publicity of these features by the Park management, tourist should not be given the impression that the Park is meant for game viewing, bird watching and observation of cultural heritage resources alone but rather should be made to realize that other features were still available that could satisfy their demand.

\section{REFRENCES}

[1] Swanswick,C and Land use Consultant (2002): Landscape Character Assessment: Guidance for England and Scotland. The Countryside Agency Cheltenham and Scottish Natural Heritage, Uk

[2] Mason, R (2002): Assessing Values in Conservation Planning: Methodological Issues and choices (Loss Angelis Getty Conservation Institute, 2002): ed. Marta de la Torre, Getty
Conservation Institute.

[3] English Heritage, (1997).

[4] Marta de la Torre and Randall Mason (2002): Introduction: Assessing the Values of Cultural Heritage tourism (Loss Angelis Getty Conservation Institute, 2002). ed. Marta de la Torre, Getty Conservation Institute

[5] Agbelusi, E.A (2009): Wildlife resources: A national heritage. Inaugural lecture delivered at the Federal University of Technology, Akure

[6] Oladeji S.O (2012): World heritage and Sustainable Development: The role of local communities: A lead paper presented at International day for Museum and Sites, $18^{\text {th }}$ April, 2012

[7] Deng, J, Qiang S, Walker, G and Zhang, Y (2003): Assessment on and Perception of Visitors' Environmental Impacts of Nature Tourism: A Case Study of Zhangiajie National Forest Park, China. Journal of Sustainable Tourism 11(6), 529-548.

[8] Robinson, D.G. et al (eds) (1976) Landscape evaluation - the landscape evaluation research project 1970-1975. University of Manchester.

[9] Craik and Zube, 1976

[10] Landscape Research Group 1988).

[11] Afolayan, T A., Agbelusi E.A., Ayodele, I.A., Balogun, A.M., Soladoye, M.O., Agbaje -Williams, B., Fasakin, E.A and Ogunmodede, M.S.(1997). Management Plan of Old Oyo National Park pp215

[12] Oladeji, S. O, Agbelusi E, A and Trevelyan , R (2012). Anthropogenic activities threatening the Management of the Ecotourism resources in Old Oyo National Park, Nigeria. Ethopian Journal of Environmental Studies and Management Vol 5. No 1, pp. 100-111

[13] Keay, R.W.J.,(1959): An outline of Nigerian vegetation. Government Printer, Lagos

[14] Charter (1970)

[15] Geerling, C. (1973). Vegetation of Upper Ogun and Old Oyo Game reserve, Department of Forestry, University of Ibadan. (February), 34-37 Publisher URL

[16] Petrides, G.A (1962): Advisory report on Wildlife and National Parks in Nigeria, 1962. A report prepared for I.U.C.N the American committee for International Wildlife Protection Special publication N0.18

[17] Ayodele A.I. (1988). Ecological basis for the management of Old Oyo National Park Ph.D Thesis Submitted to the Department of Wildlife and Fisheries, University of Ibadan.

[18] Alarape. A. (2002). Culture and Conservation in and around Old Oyo National Park. Unpublished PhD Thesis Submitted to the Department of Wildlife and Fisheries, University of Ibadan

[19] Briggs, D.J. and France, J. (1980). Landscape Evaluation: A comparative study. Journal of Environmental Management 10: 263-275.

[20] Arriaza, M.,Canas, J. F., Canas,. J, Ruiz,. P,Gonzalez,. J, and Barea,.F (2005): Landscape assessment via regression analysis. Paper prepared forpresentation at the XIth Congress 
of the EAAE (European Association of Agricultural Economists), Copenhagen, Denmark, August 24-27, 2005

[21] Arthur, L.M., Daniel, T.C. and Boster, R.S. (1977). Scenic assessment: An overview. LandscapePlanning 4: 109-129.

[22] Orland, B., Weidemann, E., Larsen, L. and Radja, P. (1995) Exploring the relationship between visual complexity and perceived beauty. Imaging Systems Laboratory, Department of Landscape Architecture, University of Illinois at Urbana-Champ aign. Internet page: http://imlab9.1andarch. uiuc.edu/projects/compleximages/complexity.html

[23] Jacques, D. L. (1980). Landscape Appraisal: The Case for a Subjective Theory. Journal of Environmental Management, 10, 107-113.

[24] Aniah Eugene, J. Eja, E.I, Judith. E. and Ushie. M.A (2009). Partronage of Ecotourism potentials as a strategy for sustainable Tourism Development in Cross-River -State. Journal of Geography and Geology. pp 2-6

[25] Avrami, E., R. Mason, and M. de la Torre, eds. 2000. Values and Heritage Conservation. Los Angeles: Getty Conservation Institute

[26] WTO (2002) Tourism proves to be a resilient and stable economic sectors (18, June) available at http.www.world tourism.org.newsroom. Release more release June 2002 .data.htm

[27] Higginbottom, K (2004). Wildlife tourism impacts, management and planning. Altona : Common Ground Publishing Pty Ltd.

[28] Lindsey, P. A, Alexander, R., Mills, M. G. L., Romanãch, S. \& Woodroffe, R. (2007). Wildlife viewing preferences of visitors to Protected Areas in South Africa: Implications for the role of ecotourism in conservation. Journal of Ecotourism, $6(1), 19-33$.
[29] Reynolds, P.C and Braitwait. D (2001). Towards a conceptual framework for wildlife tourism. Tourism management 22, $31-42$

[30] The International Ecotourism Society. (2006): The Global Ecotourism fact sheet..Washinghton D.C DC 20090-6503, USA

[31] The International Ecotourism Society. (2000): Ecotourism statistical fact sheet. N. Bennington, Vermont: The International Ecotourism Society

[32] Falade, G. O. (1993). Socio-Economic Evaluation of Wild life Based Tourism Development. In selected Conservation Areas in Nigeria (Unpublished $\mathrm{PhD}$ Thesis), submitted to the Department of Wildlife and Fisheries, University of Ibadan, Ibadan, Nigeria

[33] Macaulay Institute (2004). Review of Existing Methods of Lands cape Assessment and Evaluation .http:/ /www.mluri .sari.ac.uk/ccw/. Assessed 19.02.12 Makhzoumi J, 2000. Landscape ecology as a foundation for landscape architecture: applications in Malta. Landscape and Urban Planning 50: 1\& 3, pp. 167-177

[34] Low, S. 1981. Social science methods in landscape architecture design. Landscape Planning (8).137-148

[35] McHarg, I.[1967]. 1992. Design with Nature. Reprint, New York: John Wiley \& Sons.

[36] Haruna S.Z (2003). Abundance and distribution of Large mammals in Old Oyo National Park, Nigeria. Unpublished Postgraduate thesis submitted to Federal University of Tech., Akure

[37] Oladeji S. O and Akinrinola .O. O (2010). Potentials of Cultural Heritage tourism as basis for sustainable heritage site Development in Nigeria. Journal Applied Tropical Agriculture, vol15,pp 7-9 